\title{
РОЛЬ КОММУНИСТИЧЕСКОЙ ПАРТИИ В СУДЕБНОМ УПРАВЛЕНИИ (1930-1970)
}

\begin{abstract}
Аннотация: Предметом исследования является роль Коммунистической партии в руководстве как органами судебного управления, так и непосредственно судами. Автор статьи показывает, что партийные органы кроме принятия партийных директив по вопросам судебного строительства, оказывали воздействие на суды и органы судебного управления через решение кадровых вопросов. Используя номенклатурный принциип, руководители партийных организаций вмешивались во все сферы деятельности судов, в том числе и проиессуальную, нередко давая судьям указания по разрешению конкретных дел, а в некоторых случаях даже санкиионируя проведение уголовно-правовых кампаний, вплоть до определения времени и места проведения судебных процессов. Автор статьи приходит к выводу, что в советском государстве прочно утвердилась официальная практика вынесения партийных решений, которые приобретали фактически характер нормативных актов и воспринимались судебными органами и судьями как обязательные для исполнения. Это лишний раз свидетельствует, что в практику управления государством прочно вошло и принятие совместных решений государственных и партийных органов. В свою очередь это дает основание утверждать, что в изложенный в статье исторический период Коммунистическая партия фактически стала обладателем верховной власти в стране имаксимально консолидировала в своих руках функиии руководства любой отраслью государственного управления, в том числе, и судебной. Для получения истинных знаний о сущзности и закономерностях формирования роли Коммунистической партии в судебном управлении автор статьи обратился к историко-правовому методу. Анализ развития исследуемого явления, исторических источников, официальных документов позволил оценить начальные этапы возникновения коммунистического руководства судебными органами и увидеть его содержательную (историческую), так и формальную (юридическую) сторонь, а также показать организационно-правовые основы формирования и развития такого руководства. Научная новизна статьи обусловлена самой постановкой проблемы и тем, что цели и задачи, определенные в работе, еще не решались в отечественной юридической науке. Наряду с исследованием историко-правовых аспектов роли Коммунистической партии в судебном управлении в период с начала 1930-х и до завершения 1970-х г2., автором статьи уделено значительное внимание формам и методам воздействия партийных органов на деятельность судебных органов и органов судебного управления, практике принятия совместных решений государственных и партийных органов.
\end{abstract}

Ключевые слова: Коммунистическая партия, управление, суд, репрессии, независимость, Конституичия, нормотворчество, преступность, законность, авторитарный режим.

Abstract: The subject of the research is the role of the Soviet Communist Party in judicial administration and the governing of the courts. The author of the article shows that the party's directives have an impact on courts and judicial power. The leaders of the Soviet Communist Party interfered in all spheres of activity of the judicial power, including procedural aspects, often giving judges guidelines for solving individual cases, and in some cases, even determined the time and location for the trials. The author concludes that in the Soviet Union firmly established the official influence of party on all aspects of the powers functioning, and that the Party's decisions were perceived by the judiciary and judges as binding. This allows the author of the article to perceive this historical period of the USSR as a Communist Party's total dominance and its supreme power in the country. The whole government power of the country, including the judiciary, at this time was consolidated in the hands of the leadership of the Communist Party. The scientific novelty of this work lies in the very posing of the question and the fact the goals and tasks defined in this work have not previously been addressed in Russian legal science.

Keywords: Crime, lawmaking, Constitution, independence, repression, court, administration, Communist party, legality, authoritarian regime. 


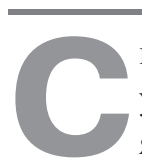
воеобразие советского судебного управления заключалось в том, что оно являлось не только отраслью государственного управления, но и важным элементом командной системы партийного руководства страной. Несмотря на то, что во многих работах В.И. Ленина[1, с.129] и в постановлениях советской власти[2, с.93] звучала идея строгого соблюдения законов РСФСР, в государственно-властных структурах стало усиливаться влияние партийного руководства, постепенно исчезал плюрализм, в рамках которого еще можно было увидеть элементы динамично развивающегося государственного механизма и ленинского представления о советской демократии. На смену им пришел партийно-бюрократический диктат, особенно ярко проявившийся в эпоху сталинизма. Это наглядно видно из слов И.В. Сталина на XVII съезде партии (1934), где он сказал, что «партию нельзя рассматривать, как нечто оторванное от окружающих людей. Она живет и подвизается внутри окружающей ее среды»[3,с.564]. Тем самым в социалистическом государстве Советам как органам власти была определена второстепенная роль. В то же время роль партии большевиков, а затем и Коммунистической партии все более возрастает. Партия стала принимать самое активное участие в государственном строительстве и во всех политических акциях, консолидируя членов партии и беспартийных партийно-политическим единством. К началу 1940-х гг. всевластие партийно-государственного аппарата утвердилось окончательно. Партия стала играть роль идеологизированного органа, деятельность ее становилась все более догматичной, а органы советской власти играли не просто второстепенную роль, а стали придатками партии. Для того чтобы понять положение судебной власти в обществе, следует обратиться к словам А.А. Жданова, одного из идеологов сталинской эпохи, который характеризуя свое отношение к исключенным из партии называл их ничем иным как «отходами нашей собственной работы»[4]. В этот исторический период важным этапом идеологической работы в стране становится «восстановление авторитета репрессии», проверка любого гражданина СССР на «благонадежность и на лояльность к режиму»[5,c.10]. Безусловно, все эти требования относились, прежде всего, к членам партии, но распространялись и на беспартийных граждан страны. В результате в стране стали процветать подозрительность, доносительство, незаконные обвинения и применение репрессивных мер. При таком положении суды и органы судебного управления были всецело подчинено коммунистическому режиму. В эти годы в стране наиболее полное и последовательное воплощение получает и абсолютная формула социалистической демократии «подчинения личных интересов общественным». По словам И.В. Сталина «Наша демократия должна всегда на первое место ставить общие интересы. Личное перед общественным - это почти ничего»[6,c.56]. Конечно, такое определение демократии заставляло суды и органы судебного управления забыть про законность и неукоснительно подчиняться действующему политическому режиму, в основе которого, к тому же, лежала жесткая кадровая, партийнокоммунистическая дисциплина. Например, руководители судебных органов, органов юстиции и прокуратуры, как правило, избирались членами выборных партийных органов (членами бюро, членами гор(рай)комов), что, безусловно, заставляло их выполнять указания и рекомендации партийных органов. В этом активную «помощь» Коммунистической партии оказывали и руководители центральных органов судебного управления. В частности, Народный комиссар юстиции СССР Н.В. Крыленко предложил «унифицировать» судебную репрессию и дать в руки партии и центральной государственной власти реальную возможность управлять судами как органами репрессии, что нельзя было сделать, по его мнению, при полной свободе «судейской совести». В этой же своей статье Н.В. Крыленко предлагает «перейти к некоторой унификации (имеется в виду упорядочение назначения наказания трибуналами и совнарсудами) для того, чтобы взять в руки суды, приучить их быть послушным орудием в руках государственной власти»[7,с.1333]. Таким образом, с помощью таких выступлений выстраивалась теоретическая концепция подчинения судебной власти партии, в том числе и государственной власти, поскольку уже произошло сращивание партийной и государственной власти. К слову сказать, партийные органы никогда не отказывались от принципа руководства судами, осуществляя его непосредственно сами либо через специализированные органы судебного управления (Наркомюст СССР и наркомюсты союзных республик, Верховный Суд СССР и верховные 
суды союзных республик). Адекватным отражением социально-политической действительности и реализма в этом вопросе явилась ст. 126 Конституции СССР 1936 года, которая квалифицировала Коммунистическую партию как «передовой отряд трудящихся в их борьбе за построение коммунистического общества» и «руководящее ядро всех организаций трудящихся, как общественных, так и государственных». Таким образом, принцип независимости судей и подчинения их только закону был сплошной мистификацией, поскольку прямое действие этого принципа правосудия не предполагалось и названная норма Конституции 1936 г. (ст. 112) не устанавливала механизмов гарантированности выполнения этого принципа, а имела цель лишь приукрашивания существующего режима.

Данные положения Конституции 1936 г. получили свою дальнейшую конкретизацию и развитие в Законе СССР «О судоустройстве СССР», принятом 16 августа 1938 года 2-й сессией Верховного Совета СССР. В нем также были отражены партийно-идеологические и организационно-функциональные принципы советского правосудия. Среди них, защита от всяких посягательств установленного Конституцией СССР и конституциями союзных и автономных республик общественного и государственного устройства СССР, социалистической системы хозяйства и социалистической собственности; политических, трудовых, жилищных и других личных и имущественных прав и интересов граждан СССР, гарантированных Конституцией СССР и конституциями союзных и автономных республик; прав и охраняемых законом интересов государственных учреждений, предприятий, колхозов, кооперативных и иных общественных организаций. В Конституции указывалось, что советский суд, применяя меры уголовного наказания, не только карает преступников, но и имеет своей целью их исправление и перевоспитание. Между тем Н.В. Крыленко как руководитель центрального органа судебного управления высказывал по этому поводу совершенно противоположную точку зрения, заведомо ориентируя суды на ужесточение наказания, а никак на исправление и перевоспитание. По его мнению, при назначении наказания «с точки зрения непосредственной задачи борьбы с преступностью он не видит аргументов, которые оправдывали бы принципы “до" и “не ниже”». Поэтому ему представлялось «более целесоо- бразной постановка уголовной репрессии так, чтобы определенные категории преступлений влекли бы за собой длительные сроки лишения свободы, однако без точного определения их предела...И как самое жесткое средство самообороны должен быть сохранен расстрел - как мера физического уничтожения»[8,c.1334].

Утверждение коммунистической диктатуры и расширение ее влияния на суды и органы судебного управления, шло одновременно с другим важным идеологическим процессом формированием послушания судей и работников органов судебного управления, которые практически все были членами партии. Например, из бюллетеня Наркомата юстиции РСФСР под грифом «Сов.секретно» видно, что на 01.07.1927г. из 2943 судей республики членами партии были $84,2 \%$; за аналогичный период 1928г. из 3063 судей $-85,9 \%$ партийных. В этом же документе приводится партийный состав среди руководителей краевых (областных) судов, который составлял 91,6\%[9,c.45-54]. Судьи и работники органов судебного управления должны были осознавать, что вне партии авторитета не бывает, а гарантией сохранения карьеры, а подчас и жизни, становилось строгое и неуклонное выполнение требований государственно партийной власти. Тем более, что этому были наглядные примеры. Так, Народный комиссар юстиции СССР Н.В. Крыленко в журнальной статье был обвинен в «юридическом нигилизме, упрощенчестве, попустительстве врагам народа, свившим при Крыленко крепкое гнездо в судебных органах и творившим свое гнусное дело». В связи с чем в этой статье предлагалось «до конца выкорчевать крыленковщину и сделать юстицию крепостью против врагов». Заканчивалась она (статья) достаточно в угрожающем тоне: «Прежнее руководство НКЮ СССР, развалившее судебную работу, сметено... По тяжелому наследству крыленковского руководства, по тем работникам, которые не перестроили свою работу в соответствии со Сталинской Конституцией, журнал направляет свой удар»[10]. Безо всякого труда понятно, что становилось с теми, кто оказывался в стане «врагов народа» в судах или органах юстиции.

О том, что ожидает тех, кому партия отказывала в поддержке, хорошо видно и из заметок того же А.А. Жданова. Он писал: «О личных авторитетах. Поскольку партия поддерживает. Если партия откажет от поддержки, мокрого 
места не останется». После этих слов автор названных заметок делает следующее примечание: «припугнуть, как следует»[11].

Поэтому среди судейского корпуса и работников органов судебного управления сформировалась так называемая «элита военно-приказной системы» умевших организовать самих себя, мобилизовать равных себе, нижестоящих судей и судебную систему в целом «на выполнение партийных директив, проявляя ту степень жесткости, которая необходима для достижения необходимого результата»[12].

Безусловно, такой партийный диктат и утверждение сталинской идеологии дали свои плоды. С усилением репрессий судебное управление как отрасль государственного управления и партийного руководства представляет собой уже особый, своеобразный рычаг партийно-государственного механизма, существенно отличающийся от других органов государственного управления. Перед судебным управлением ставятся довольно конкретные задачи борьбы с преступностью. Суд должен был «беспощадно карать расхитителей социалистической собственности, воров, мошенников, спекулянтов, хулиганов, лодырей, прогульщиков и летунов. Выжигать еще сохранившиеся в советской жизни родимые пятна капитализма. Средствами принуждения бороться с пережитками капитализма в сознании людей, убирать и изолировать, карать и перевоспитывать носителей этих пережитков»[13].

В результате появилось партийное нормотворчество, оказавшее существенное влияние и на процессы судебного управления. Документы, создаваемые РКП(б), Коммунистической партией, стали играть большую роль в процессе правотворчества Советского государства, иногда прямо являясь источниками права и подменяя законодательные акты, то есть приобретали высшую юридическую силу. Среди таких партийных документов можно выделить две формы партийного правотворчества. В первом случае это сугубо партийные документы, затрагивающие организационные вопросы формирования и функционирования государственных институтов. Например, на XIV партийной конференции ВКП(б) (27-29 апреля 1925) впервые дается понятие «революционной законности», под которой понимается единообразное понимание и обязательное выполнение всех законов советской власти, недопущение самостоятельного толкования законов местными органами власти[14,с.385]. Обеспечение революционной законности рассматривалось как метод построения новых производственных отношений и ее выполнение увязывалось с осуществлением социально-экономической политики государства[15]. Таким образом, по своему содержанию и своей роли такого рода партийные документы выходили за рамки исключительно партийных установлений и рассматривались как политическая директива органам государственной власти, должностным лицам и даже гражданам.

Ко второй форме партийного правотворчества относятся совместные постановления правительства и руководящего партийного органа по вопросам судебного управления. В основном они принимались в следующем формате: ЦК ВКП(б) (КПСС) и СНК (СМ) СССР. Особенно широкое распространение принятие таких совместных постановлений получило в 1930-е гг. Для иллюстрации сказанного приведем несколько таких совместных постановлений, связанных в том числе и с деятельностью судебных органов: СНК СССР и ЦК ВКП(б) от 17 ноября 1938 г. «Об арестах, прокурорском надзоре и ведении следствия»; ЦК ВКП(б) и СНК СССР от 27 мая 1939 г. «О мерах охраны общественных земель колхозов от разбазаривания»; СНК СССР и ЦК ВКП(б) от 1 декабря 1938 г. «О порядке согласования арестов»; ЦК КПСС и Совета Министров СССР от 23 июля 1966 г. постановления «О мерах по усилению борьбы с преступностью»; ЦК КПСС и Совета Министров СССР от 30 июня 1970 г. «О мерах по улучшению работы судебных и прокурорских органов», и др.

После принятия таких совместных документов они становились обязательными не только для партийных органов и членов партии, а правовыми актами, имеющими общеобязательный юридический характер. Поэтому совместные партийно-государственные постановления стали восприниматься как инструмент государственной политики, в том числе и в области судебного управления, воздействующий на жизнедеятельность судебной системы. Таким образом, в судебной сфере укоренилось положение о безусловном примате решений партийных органов над правом. В пирамиде системы судебного управления важную роль играли установки и правила, исходившие от вышестоящих партийных органов (Центрального Комитета ВКП(б) (КПСС) и их Политбюро). В этих усло- 
виях партийное «нормотворчество» фактически стало одним из методов судебного управления. Провозглашенный еще до войны конституционный принцип (ст. 112 Конституции СССР 1936 г.) о независимости судей и подчинения их только закону в народе был метко перефразирован следующим образом: «Судьи подчиняются закону и райкому». Судебное управление рассматривалось партийными органами как инструмент государственной власти, которым партийные органы успешно манипулировали. Партийные органы на любом уровне могли подвергнуть ревизии работу судов и органов судебного управления и решать любые организационные вопросы, связанные с судебной деятельностью. В этом отношении достаточно интересна докладная записка председателя Курганского окружного суда окружному комитету ВКП(б) «Об участии окрсуда в работе по ликвидации кулачества как класса» от 6.03.1930г. В ней руководитель суда докладывает о проведенной судом работе по борьбе с кулачеством и в конце объясняет как судьи справляются с такой трудоемкой работой. Как указывает председатель, «днем судьи судят, разбирают судебные дела, а ночью выезжают в сельсоветы как уполномоченные по ликвидации кулачества»[16].

Партийные органы брали на себя даже рассмотрение чисто организационных вопросов судебного управления. Так, 21.04.1945 г. было проведено заседание бюро Курганского обкома ВКП(б) с повесткой дня: «О созыве кустовых семинаров заместителей председателей народных судей Курганской области» и «Об организации областных юридических курсов по подготовке и переподготовке судебных работников», которым разрешалось областному управлению Наркомюста РСФСР, во-первых, провести трехдневный семинар заместителей председателей народных судей в первой половине июня 1945 г.; и, во-вторых, организовать и провести областные 3-месячные курсы по подготовке и переподготовке судебных работников в городе Кургане в период с 15 мая по 1 сентября 1945 года с контингентом 40 человек[17].

О какой можно было говорить независимости и самостоятельности, если партийные органы, проводя проверки в судах, давали указания по вопросам граничащим с их процессуальной деятельностью и по вопросам, входящим в компетенцию органов судебного управления. В 1950 г. административным отделом Свердловского обкома КПСС была проведена проверка работы Свердловского областного суда. Несмотря на то, что деятельность суда была признана удовлетворительной, в ходе проверки были выявлены, как указывается в справке, «нарушения сроков рассмотрения дел; неправильное применение закона; отсутствие анализа судебной практики; ненадлежащее руководство народными судами и недостаточность мер по повышению качества работы последних». При этом указывалось, что председатель областного суда не уделял внимания проведению оперативных совещаний в областном суде[18]. И такой контроль за деятельностью судебных органов и органов судебного управления со стороны Коммунистической партии был повсеместным.

Следует отметить, что репрессивный механизм государства раскручивался под благовидными предлогами борьбы с преступностью, вредительством, саботажем и другими противоправными явлениями, которые мешают строительству социалистического и коммунистического будущего. Коммунистическая партия, которая еще задолго до провозглашения ее в ст. 126 Конституции СССР 1936 г. руководящей и направляющей, прекрасно понимала, что это наиболее действенное средство пресечения всякого рода оппозиционной деятельности и наиболее эффективный инструмент проведения классовой политики и установления политико-идеологического единомыслия. В то же время, начавший набирать обороты к концу1920-х гг. авторитарный режим, способствовал интенсивному утверждению в стране командно-административной системы управления, что самым непосредственным образом повлияло на независимость и самостоятельность судей и всей судебной системы Советского государства. Наглядным примером тому является постановление ЦИК и СНК СССР от 7 августа 1932 г. «Об охране имущества государственных предприятий, колхозов и кооперации и укреплении общественной (социалистической) собственности». В нем без внесения каких-либо изменений в действующее уголовное законодательство, в категоричной форме дается указание судам о применении к виновным в хищении имущества государственных предприятий, колхозов и кооперации расстрела с конфискацией всего имущества. И только в исключительных случаях при наличии смягчающих обстоя- 
тельствах разрешалось заменять расстрел на лишение свободы, но на срок не ниже 10 лет с конфискацией имущества. При этом особо выделялись репрессивные меры в отношении кулацких и других противообщественных элементов, совершивших насилие в отношении колхозников. Их предписывалось заключать в специальные концентрационные лагеря сроком от 5 до 10 лет.

Под партийной опекой в стране формируются и органы внесудебной репрессии, которые были наделены широчайшими полномочиями, в том числе и судебными. Так, в приказе ОГПУ СССР от 2 февраля 1930 г. предлагается немедленно ликвидировать «кулацкий актив», а наиболее богатых из них выселить. В целях наиболее организованного проведения данной кампании и оперативного рассмотрения дел указанной категории при полномочных представительствах ОГПУ СССР образуются судебные коллегии[19,с.106-110]. С каждым годом полномочия этого псевдосудебного органа расширяются. Особенно отчетливо это видно из постановления ЦИК СССР от 14 марта 1933 г. «Об ответственности служащих в государственных учреждениях и предприятиях за вредительские акты», которым судебной коллегии ОГПУ СССР по делам о диверсиях, поджогах, взрывах, порче имущества государственных предприятий и прочим видам вредительства дается право применять меры репрессии с особой строгостью. Данное постановление совпадает и с другим специальным постановлением ЦИК СССР, которым судебной коллегии ОГПУ СССР предоставляется право при рассмотрении дел о вредительских актах применять любые меры уголовного наказания, вплоть до расстрела. В 1930 -е гг., как указывает Д. Волкогонов, И.В. Сталин пишет, что судебная коллегия ОГПУ «представляет что-то вроде трибунала»[20 ,с.242,246,300-301]. Проводимые им массовые мероприятия по применению «арестов и острых форм репрессий», нашли свое отражение в совместной Инструкции СНК СССР и ЦК ВКП(б) от 8 мая 1933 г. В ней хорошо видно повсеместное применение внесудебных репрессивных мер, граничащих с произволом и беззаконием. Например, на момент принятия названной выше Инструкции в ЦК ВКП (б) имелись, так называемые, заявки на немедленное выселение из областей и краев около ста тысяч семей, подпадающих под определение кулаков. Этот период также характеризуется массовыми и беспорядочными арестами, проводимыми председателями колхозов и сельских советов, районными и краевыми уполномоченными и даже членами правлений колхозов и секретарями партийных ячеек, то есть совершенно не уполномоченными на то должностными лицами[21]. По этому вопросу партийные органы организовали разъяснительную работу с направлением на места писем следующего содержания: «аресты производятся только органами ОГПУ, НКЮ и уголовным розыском. Аресты другими лицами и учреждениями категорически воспрещаются. Прокурору проследить за выполнением настоящей директивы»[22].

В довоенный период одним из направлений деятельности НКВД СССР становится расследование преступлений. Для придания законности проводимой в стране репрессивной кампании, в составе Верховного Суда СССР, Верховных судах союзных республик, краевых (областных) и приравненных к ним судам организуются специальные судебные коллегии в составе председателя и двух членов суда, куда следственному аппарату НКВД СССР и его местным органам предписывается по окончании следствия направлять уголовные дела для рассмотрения. В свою очередь уголовные дела об измене Родине, шпионаже и различных видах диверсий подлежат рассмотрению Военной коллегией Верховного Суда СССР и военных трибуналов округов по подсудности, а дела о преступлениях на железнодорожном и водном транспорте транспортной и водной коллегией Верховного Суда СССР, а также линейными железнодорожными и водными судами. Одновременно этим постановлением наркому внутренних дел предоставляется право организации особого совещания, которое во внесудебном порядке широко применяет такие репрессивные меры, как высылка, ссылка, заключение в исправительно-трудовые лагеря на срок до 5 лет и высылку за пределы СССР.

Таким образом, к принятию Конституции СССР 1936 г. в стране сложилась достаточно парадоксальная ситуация. С одной стороны, в Основном законе закрепляются основополагающие принципы судоустройства и судопроизводства: гласность судебного разбирательства, за исключением случаев, предусмотренных законом, независимость судей и подчинение их только закону, неприкосновенность лично- 
сти, неприкосновенность жилища граждан и тайна переписки. То есть создается видимость принятия мер по укреплению законности в деятельности органов дознания и следствия, суда и прокуратуры. С другой - становится совершенно очевидным разгул и размах внесудебных и судебных репрессий, в самых грубых формах массовое нарушение прав человека, резкое сужение процессуальных гарантий лиц, привлекаемых к уголовной ответственности, и расширение возможностей для вынесения не только необоснованных, но и неправосудных приговоров. Одновременно с этим происходит и падение авторитета судебных органов, поскольку по наиболее значимым для государственной безопасности уголовным делам приговоры в действительности выносятся не судом, а в политбюро ЦК ВКП(б), суд же их только озвучивает. Например, по данным, приведенным Д. Волкогоновым, в эти годы в ЦК ВКП(б) из органов внутренних дел поступает более четырехсот списков на лиц, в отношении которых испрашивается согласие на применение к ним высшей меры наказания. И только после соответствующей санкции ВКП(б) эти списки направляются в военные трибуналы[23]. Безусловно, такое положение следует рассматривать даже не как вмешательство в судебную деятельность, а как присвоение партийными органами судебных полномочий.

Вмешательство партийных органов в деятельность судебных не завершилась эпохой сталинизма. Правда такое вмешательство не стало столь острым и грозящим для судейского корпуса и органов судебного управления репрессиями, подобными в 1930 и 40-е гг. Тем не менее, указания партийными органами продолжали даваться, но в основном через органы судебного управления (Верховный
Суд РСФСР (СССР), краевые (областные) суды, Министерство юстиции РСФСР (СССР), краевые (областные) управления и отделы юстиции), причем с обязательными ссылками на решения съездов и пленумов ЦК КПСС. Партийные органы через судебное управление продолжают ограничивать суды жесткими рамками идеологической парадигмы «строительства коммунизма». В пирамиде системы правовых норм продолжается монополия совместных постановлений партийно-государственных структур. Партийные установки, задачи, указания, исходящие от ЦК КПСС либо от его структурных подразделений - Политбюро (Президиума), Оргбюро, Секретариата, отделов, в силу уже сложившегося политического обычая имеют приоритет перед любыми другими правовыми актами.

Таким образом, можно прямо сказать, что по традиции, укоренившейся еще в середине 1930-х гг., суды продолжали (и это было практически до завершения советского периода развития государства) оставаться важным элементом командно-административной системы страны и выступать более всего как репрессивные органы по выполнению задач, поставленных центральными партийными органами. Подтверждением тому служит приветственное письмо участников торжественного собрания, посвященного 60-летию советского суда (декабрь 1977). В нем указывается, что советские судьи заверяют Коммунистическую партию, правительство и лично Л.И. Брежнева (Генерального секретаря ЦК КПСС) в том, что работники судов и органов юстиции еще настойчивее будут работать по претворению в жизнь решений XXV Съезда КПСС, внесут достаточный вклад в осуществление предначертаний ленинской партии[24].

\section{Библиография:}

1. Ленин В.И. Наброски тезисов Постановления о точном соблюдении законов// Полн. собр. соч. Т. 37 . С. 129.

2. Постановление Чрезвычайного VI Всероссийского Съезда Советов «О революционной законности»// Съезды Советов в документах. М., 1959. Т. 1. С. 93.

3. ВКП(б) в резолюциях и решениях съездов конференций и пленумов ЦК. Изд. 5-е. М., 1936. Ч.2. С.564.

4. РГАСПИ. Ф.77 ОП.3с. Д.115 Л. 17.

5. Жданов А.А. Уроки политических ошибок Саратовского крайкома. М.: Партиздат ЦК ВКП(б), 1935. С. 10.

6. Волкогонов Д. Триумф и трагедия. И.В. Сталин. М., 1989. Кн. І. Ч. 2. С. 56.

7. Крыленко Н.В. На рубеже // Еженедельник советской юстиции. 1927. № 43. С. 1333.

8. Крыленко Н.В. Указ. соч. С.1334

9. ГАКО. Ф. р-475. Оп.1. Д.287. Л.45-54.

10. Ширманов И.А. Н.В. Крыленко о ликвидации гарантий в уголовном судопроизводстве //История государства и права. 2009. № 12; Советская юстиция. 1938. № 4. С. 27-28. 
DOI: $10.7256 / 1811-9018.2016 .6 .14126$

При цитировании этой статьи сноска на dоі обязательна

Право и политика $6(198) \cdot 2016$

11. Глотова О.А. Изменения в системе подготовки сталинских партийных кадров в связи с публикацией Краткого курса истории ВКП(б)//Международный исторический журнал. 2002. №20.

12. Ахиезер А., Клямкин И., Яковенко И. История России: конец или новое начало? / 2е изд., испр. и доп.М.: Новое издательство, 2008. С.225.

13. Правда. 1941. 20 января.

14. Коммунистическая партия Советского Союза в резолюциях и решениях съездов, конференций и пленумов ЦК. Т. 3. С. 385.

15. Мигущенко О.Н. Обеспечение законности в деятельности Советского государства в 20-30-е годы XX в. // URL: urist lip.ru.

16. ГАКО.Ф.р-475. Оп.1. Д.274. Л.26.

17. ГАКО.Ф. 166. Оп. 2. Д. 47. Л. 9.

18. ГАСО. Ф.148-р. Оп.1. Д.353. Л.62.

19. Сборник законодательных и нормативных актов о репрессиях и реабилитации жертв политических репрессий. М.: Республика, 1993. С.106-110.

20. Волкогонов Д. Указ. соч. С. 242, 246, 300,301.

21. Вопросы истории. 2001. №9. С.16-20.

22. ГАКО. Ф. р-475.Оп.1.Д.272.Л.4.

23. Волкогонов Д. Указ. соч. С. 301.

24. Советская юстиция. 1978. № 2.

\section{References (transliterated):}

1. Lenin V.I. Nabroski tezisov Postanovleniya o tochnom soblyudenii zakonov// Poln. sobr. soch. T. 37. S. 129.

2. Zhdanov A.A. Uroki politicheskikh oshibok Saratovskogo kraikoma. M.: Partizdat TsK VKP(b), 1935. S. 10.

3. Volkogonov D. Triumf i tragediya. I.V. Stalin. M., 1989. Kn. I. Ch. 2. S. 56.

4. Krylenko N.V. Na rubezhe // Ezhenedel'nik sovetskoi yustitsii. 1927. № 43. S. 1333.

5. Krylenko N.V. Ukaz. soch. S.1334

6. Shirmanov I.A. N.V. Krylenko o likvidatsii garantii v ugolovnom sudoproizvodstve //Istoriya gosudarstva i prava. 2009. № 12; Sovetskaya yustitsiya. 1938. № 4. S. 27-28.

7. Glotova O.A. Izmeneniya v sisteme podgotovki stalinskikh partiinykh kadrov v svyazi s publikatsiei Kratkogo kursa istorii VKP(b)//Mezhdunarodnyi istoricheskii zhurnal. 2002. №20.

8. Akhiezer A., Klyamkin I., Yakovenko I. Istoriya Rossii: konets ili novoe nachalo? / 2e izd., ispr. i dop.M.: Novoe izdatel'stvo, 2008. S.225.

9. Migushchenko O.N. Obespechenie zakonnosti v deyatel'nosti Sovetskogo gosudarstva v 20-30-e gody XX v. // URL: urist lip.ru.

10. Volkogonov D. Ukaz. soch. S. 301. 